\title{
DAKWAH MEDIASI : PERSPEKTIF SEJARAH ISLAM
}

\author{
HM. Yakub
}

\begin{abstract}
Abstrak
Dakwah merupakan jalan yang di tempuh untuk menyebarluaskan ajaran Islam, dengan dakwah Islam dapat disebarkan sampai kepenjuru dunia. Namun dalam proses dakwah terkadang sering menemui benturan dan hambatan, salah satunya dalam menangani konflik horizontal maupun konflik vertikal di tengah masyarakat, dari masalah ideologi, pemahaman dan bahkan pemikiran yang saling berbeda. Di sinilah dibutuhkannya mediasi dalam dunia dakwah. Perlu kita pahami bahwa mediasi menengahi atau penyelesaian sengketa melalui penengah yang disebut sebagai mediator. Untuk itu sistem mediasi, mencari penyelesaian masalah melalui mediator. Penjelasan mengenai mediasi merupakan salah satu alternatif penyelesaian konflik sebagai terobosan atas cara-cara penyelesaian tradisional melalui litigation.
\end{abstract}

Kata kunci : Dakwah, Perspektif, dan Sejarah Islam

\section{A. PENDAHULUAN}

Dalam mediasi, seluruh pihak yang bertikai, konflik dan berseteru duduk bersama secara pribadi, untuk saling berhadapan antara yang satu dengan yang lain. Seluruh pihak berhadapan dengan mediator sebagai pihak ketiga yang netral dan objektif. Sungguh peran dan fungsi mediator sangat membantu untuk seluruh pihak dalam mencari jalan keluar atas penyelesaian konflik dan masalah. Penyelesaian yang hendak diwujudkan dalam mediasi adalah compromise atau kompromi di antara para yang saling berselilih pendapat dan paham. Untuk mencapai kata kesepakatan mediator menegaskan serta memperingatkan untuk jangan sampai salah satu pihak cenderung untuk mencari kemenangan, dalam artian harus trasnparan dan objektif.

Jikalau terjadi masalah yang sangat sensitif atara para pihak konflik dan pertikaian akan terjebak pada yang dikemukakan Joe Macroni yaitu apabila salah satu pihak ingin mencari kemenangan, akan mendorong masing-masing pihak menempuh jalan sendiri (I have may way and you have your way). Akibatnya akan terjadi jalan buntu (there is no the way). Tidak memiliki titik terang dalam menghadapi permasalahan yang terjadi. Di sinilah kearifan dakwah yang memiliki fungsi peranan penting dalam mengajak, menyeruh orang lain agar dengan berlapang dada meraih kemuliaan disisi Allah. Oleh sebab itu dakwah yang 
sesungguhnya mampu melahirkan dan menciptakan kedamaian dan kemuliaan di tengah kehidupan. Islam sebagai agama yang rahmatan lil'alamin yang dibawa oleh Nabi Muhammad telah membawa arah perubahan secara signifikan untuk membangun peradaban yang lebih tinggi yaitu mewujudkan kehidupan manusia yang penuh dengan kedamaian. Banyak catatan sejarah peristiawa bahwa Muhammad telah mengajarkan kepada umat untuk melakukan kemuliaan dengan jalan perdamaian. Maka dalam tulisan kali ini penulis mencoba memahami bahwa pentingnya mediasi dakwah dalam kehidupan umat Islam dalam perspektif sejarah.

\section{B. Mediasi Dalam Lintasan Sejarah Islam}

Setelah didirikan nabi Ibrahim Ka'bah roboh beberapa kali. Ketika Ka'bah roboh untuk pertama kalinya karena banjir, kabilah Amaliqah membangunnya kembali. Tatkala roboh untuk yang kedua kalinya, kabilah Jurhum membangunnya kembali. Pada roboh yang ketiga kalinya, kaum Quraisy yang membangunnya. Pada saat itu, Muhammad sudah menjadi pemuda dewasa. Menurut riwayat Abdur Razaq dan Ibnu Ishaq, usia Beliau saat itu 35 tahun.

Di masa Qusai bin Kilab, Hajar Aswad sempat hilang diambil oleh anakanak Mudhar bin Nizar dan ditanam di sebuah bukit. Qusai adalah orang pertama dari bangsa Quraisy yang mengelola Ka'bah selepas nabi Ibrahim. Di masa Qusai ini, Ka'bah ditinggikan menjadi 25 hasta dan diberi atap. Setelah Hajar Aswad ditemukan, Qusai meletakkannya kembali. Ketika roboh untuk yang ketiga kali, kabilah-kabilah yang ada bergotong royong memperbaiki Ka'bah. Namun tidak ada yang berani menyentuh Hajar Aswad. Ketika semuanya selesai, mulailah percekcokan mengenai siapa yang berhak memindahkan Hajar Aswad. Suasana semakin memanas setelah Bani Abdud Durar dan Syam membawa baskom berisi darah. Baskom darah merupakan simbol bahwa mereka akan mengerjakan sesuatu hingga titik darah penghabisan. Suasana genting tersebut berlangsung selama kurang lebih 5 hari. $^{1}$

${ }^{1}$ Zulkarnain, Muhammad dan Peletakan Hazar Aswad, Disarikan dari seri kajian sirah Nabawiyah di Masjid Salman ITB pada 11 Januari 2011. 
Muhammad pada usia 35 tahun, lima tahun sebelum kenabian Muhammad ada suatu peristiwa yaitu Mekkah dilanda banjir besar hingga meluap ke Baitul Haram yang dapat meruntuhkan Ka'bah. Karena peristiwa itu, kaum Quraisy sepakat untuk memperbaiki Ka'bah, dan yang menjadi arsitek adalah orang romawi bernama Baqum. Imam Ahmad dan beberapa ahli sejarah menuturkan pada saat kaum Quraisy berselisih pendapat tentang siapa yang berhak meletakkan kembali Hajar Aswad ke tempat semua, segologan dari mereka berpendapat untuk mencari seorang penengah. Kemudian mereka sepakat bahwa yang berhak menjadi penengah adalah orang yang pertama kali keluar dari salah satu jalan di kota Makkah. Sesaat kemudian, tiba-tiba yang muncul pertama kali adalah Muhammad. Mereka pun lalu berkata, "Lihatlah, kita telah kedatangan orang yang sangat bisa dipercaya (Al-Amin)". Mereka menyampaikan kesepakatan yang telah mereka buat kepada Muhammad. Muhammad tidak egois meletakkan hajar aswad sendirian, meskipun beliau berhak dengan kesepakatan yang telah dibuat. Beliau memilih untuk menyatukan kabilah-kabilah yang hampir terpecah tersebut. ${ }^{2}$

Muhammad bangkit dan meletakkan Hajar Aswad di atas sebuah kain panjang. Setelah itu, Beliau memanggil seluruh kepala kabilah untuk bersamasama mengangkat Hajar Aswad ke tempat semula. Terlihat para kepala kabilah memegang tepi kain tersebut. Kemudian mereka berjalan menuju ke dekat Ka'bah, lalu mereka berhenti. Muhammad kemudian mengambil Hajar Aswad dengan kedua tangannya serta meletakkannya kembali ke tempatnya. Dari cerita ini, setidaknya ada 2 hikmah yang bisa dipetik, yaitu:

1. Kepuasan kaum Quraisy terhadap solusi yang diberikan oleh Muhammad untuk menyelesaikan perselisihan di antara mereka. Gelar Al Amin dari mereka untuk Muhammad, merupakan bukti bahwa perilaku beliau selalu dibimbing Allah. Rekam jejak inilah yang membuat bangsa kaum Quraisy tidak bisa secara terang-terangan menolak kenabian Muhammad.

http://salmanitb.com/2011/01/16/muhammad-dan-peletakan-hajar-aswad/, di akses pada tanggal 11 November 2015 pada pukul 22.30 WIB

${ }^{2}$ Zulkarnain, Muhammad dan Peletakan Hazar Aswad, Disarikan dari seri kajian sirah Nabawiyah di Masjid Salman ITB pada 11 Januari 2011 
2. Peran Muhammad di tengah-tengah penduduk Makkah pada waktu itu sangat beragam. Peran ini meliputi seluruh sisi kehidupan sosial yang ada. Rasulullah selalu terlibat pada berbagai peristiwa penting seperti masalah Hajar Aswad ini, dan sebelumnya perang Fijar serta perjanjian Hilful Fudhul. Peran positif beliau senantiasa dilandasi satu tujuan mulia, yaitu menempatkan yang haq pada tempatnya dan menegakkan nilai-nilai kebenaran serta keadilan.

Jauh saat Islam belum hadir Yatsrib tidak memiliki pemimpin dan pemerintah resmi, hanya terbatas pada sistem pemerintahan kepala suku atas anggota-anggota sukunya sehingga mereka hanya mementingkan suku mereka dan selalu bersaing pada permusuhan dan peperangan antar suku. Di mana wilayah ini dikuasai oleh kaum Yahudi baik dalam bidang ekonomi, perdagangan dan penguasaan lahan pertanian. ${ }^{3}$ Pada tahun $618 \mathrm{M}$ kota Yatsrib dilanda perang antara kaum Yahudi dengan kaum Arab. Kaum Yahudi menggunakan pola adu domba dengan menyebarkan rasa permusuhan dan kebencian antara suku Aus dan Khazraj. Suku Khazraj bersekutu dengan Bani Qainuqa, sedangkan suku Aus bersekutu dengan Bani Quraizah dan Bani Nadir yang puncak peperangannya dinamakan perang Bu'as. Setelah perang usai, mereka sadar yang pada akhirnya sepakat untuk mengangkat Abdullah Bin Muhammad dari suku Khajraj sebagai pemimpin mereka sebab Abdullah dianggap berpandangan luas. Kemudian pada tahun 620 M. masyarakat suku Kajraj banyak yang menjalankan ibadah haji dan ketika berkemah di Makkah mereka ditemui oleh Muhammad. Untuk memperkenalkan Islam dan mengajak bertauhid kepada Allah sehingga kaum Khajraj berjanji untuk masuk Islam dan mengajak masyarakat Yatsrib untuk turut menganutnya. ${ }^{4}$

Agama Islam di Madinah bukan hanya mencari posisi aman dari ancaman kafir Quraisy Makkah atau mencari suaka politik saja untuk Muhammad dan kaum Muhajirin. Akan tetapi ada misi lain yang dibawa oleh Muhammad dan kaum Muhajirin. Muhammad dan kaum Muhajirin dalam penyebaran Islam di

\footnotetext{
${ }^{3}$ Tim Penulis Al Mizan, Ringkasan Materi Al Mizan, ( Mizan Press, Purwokerto, 2001), hlm. 38

${ }^{4}$ Badri Yatim, Historiografi Islam, (Jakarta :Logos Wacana Ilmu, 1997), hlm 54
} 
Madinah dapat dikatakan diterima oleh masyarakat setempat karena pada dasarnya masyarakat tersebut yang belum mengenal Islam mereka sudah mengenal adanya Tuhan disamping itu juga karena sudah adanya perjanjian atau sering disebut Baiat Aqobah I dan II.

Pada saat kehadiran Muhammad bersama kaum muslimin Mekkah atau yang disebut kaum muhajirin sangat disambut dengan gembira dan penuh rasa persaudaraan oleh masyarakat Madinah yang kemudian disebut dengan kaum ansor. Dengan adanya hubungan atau respon baik semacam itu berarti Islam dan muhajirin mendapat lingkungan baru yang bebas dari ancaman para penguasa Quraisy Makkah. Sehingga Muhammad dan pengikut dari Makkah dapat melanjutkan dakwahnya dan menjabarkan dalam kehidupan sehari-hari. ${ }^{5}$

Demikian Muhammad tetap merasakan rasa nyaman akan tetapi beliau tidak mudah terlena dengan segala kondisi yang ada. Sudah kita ketahui bahwa Muhammad datang di Madinah tidaklah seorang diri melainkan ada pengikutnya. Kaum Muhajirin atau orang Makkah yang secara langsung di tempat barunya ada hubungan dengan orang-orang yang belum masuk Islam kemudian tidak senang dengan terbentuknya masyarakat muslim di sekitarnya. Selain itu juga harus waspada terhadap ancaman Quraisy Makkah yang kemungkinan sewaktu-waktu datang. Hal ini menjadi sebuah pertimbangan yang harus dipikirkan oleh Muhammad dan tidak bisa diabaikan.

Muhammad mulai mengatur dan menyusun segenap potensi yang ada dalam lingkungannya, pemecahan permasalahan-permasalahan yang dihadapi dengan menggunakan segala potensi dan kekuatan yang ada dalam rangka menyusun masyarakat baru yang terus berkembang dan mampu menghadapi segenap tantangan dan rintangan dari luar dengan kekuatan sendiri. Mengubah nama Yatsrib Menjadi Madinah, pembentukan Piagam Madinah, pembangunan Masjid Nabawi Pada Tahun 622 M sebagai Pusat Ibadah pemerintahan, mengubah Arah Kiblat (yang awalnya Menghadap Masjidil Aqso di Palestina kemudian menghadap ke arah Masjidil Haram di Makkah), mempersaudarakan Kaum

${ }^{5}$ Zuhairini, Sejarah Pendidikan Islam, Cet VI, (Bumi Aksaara : Jakarta, 2006), hlm 32 
Muhajirin dengan Ansor, membangun sistem pertahanan, membangun Majelis Syuro, dan membangun Sarana perekonomian. ${ }^{6}$

Adapun piagam Madinah yang dijadikan sebagai Undang-undang dasar memuat hak antara Muslim dan non-Muslim yang isinya adalah "Dengan nama Allah, telah ditetapkannya oleh Muhammmad, Nabi Allah bahwa semua orang beriman baik dar suku Qurays, Suku Madinah maupun dari mana saja adalah satu negara. Perdamaian dan peperangan akan mengikat semua umat Islam. Tidak seorangpun diantara mereka mengadakan perdamaian maupun peperangan dengan musuh-musuh dari teman seagamanya. Orang Yahudi yang ikut serta menggabungkan diri dalam negara Islam Akan dilindungi dari semua gangguan serta memiliki hak-hak yang sama. Orang Yahudi bersama umat Islam akan membentuk suatu bangsa campuran dan mereka akan mengamalkan agama mereka sama bebasnya dengan umat Islam. Sekutu orang Yahudi akan menapatkan keamanan dan kebebasan yang sama. Sekutu orang Yahudi dan umat Islam akan dihormati sebagai penyokong. Semua umat Islam yang sejati akan memandang rendah terhadap orang yang berbuat kejahatan dan tidak akan melndunginya meskipum dia adalah saudara dekatnya. Orang yang bersalah akan dituntut dan dihukum. Orang Yahudi akan bergabung debgan orang Islam dalam mempertahankan kota Madinah. Kota Madinah merupakan tmpat suci dan aman bagi semua orang yang mengakui piagam ini. Orang-orang Yahudi dan sekutu umat Islam tidak akan mengadakan persetujuan dengan musuh umat Islam untuk melawan umat Islam. Semua perselisihan dimasa depan akan diserahkan kepada Nabi Muhammad SAW". ${ }^{7}$

Risalah yang di bawah oleh Muhammad yaitu keteladanan dan bimbingannya yang diberikannnya telah membawa dampak yang sangat signifikan, sehingga banyak yang datang menyatakan keislaman mereka, sehingga kaum muslim semakin banyak. Dengan terbentuknya kebijakan tersebut secara langsung terbentuklah sebuah negara sebab sudah memiliki fasilitas pendukung untuk terbentuknya sebuah negara. Inilah sebuah bentuk nyata dalam pemikiran

\footnotetext{
${ }^{6}$ Muh. Asnawi, Sejarah Kebudayaan Islam Jilid 3, (Aneka Ilmu : Semarang, 2008), hlm $27-28$

${ }^{7}$ Muhammad Husain Haekal, Sejarah Hidup Muhammad, (Jakarta : Tintamas Indonesia, 1984), hlm 233
} 
Muhammad dimana sebuah kebebasan beragama sangat dihargai, hal ini dapat dijadikan sebagai kiblat politik, sosial, budaya maupun kebijakan beragama sebagai penerapan konsep iman, islam dan ikhsan bagi umat Muhammad pada era modern yang jauh dari dimensi ke-Nabian.

Muhammad memiliki problem dan persoalan yaitu pertama yaitu urusan tempat tinggal. Untuk sementara para Muhajirin dapat menginap di ruah-rumah kaum Ansor, akan tetapi Muhammad sendiri memerlukan tempat tinggal khusus untuk dijadikan sebagai pusat kegiatan dan wujud persatuan dan kesatuan antara dua kelompok yang ada. Oleh karena itu kegiatan yang pertama kali dilakukan adalah membangun masjid yang difungsikan sebagai pusat ibadah dan pemerintahan. Dalam pembangunan masjid tersebut, Muhammad turut bekerja yang dibantu oleh kaum Muhajirin dan Ansor. Setelah masjid usai kemudian di sekelilingnya dibangun pula rumah-rumah sederhana yang dikerjakan sesuai denngan petunjuk dari Muhammad. Setelah usai pembangunan Masjid dan rumah kemudian Muhammad menempati sebagian ruangan yang memang diperuntukkan kepada beliau. Demikian pula antara kaum Muhajirin yang tidak mampu membangun rumah sendiri yang kemudian mereka sebut dengan Ahl al Suffah.

Untuk mengamati kebijakan Muhammad pada pembahasan Kebijakan di Madinah yaitu membangun kekuatan sosial semisal dengan cara menikahkan kaum Muhajirin dan Ansor, kemudian dilihat dari sisi politik membangun sistem pemerintahan yang keduanya didukung oleh kebijakan-kebijakan yang lain seperti ekonomi, pertahanan, persatuan dan pengelolaan negara.

Setelah usai pembentukan masyarakat baru membangun sosial politik, tugas Muhammad selanjutnya adalah membina masyarakat dengan segala potensi dan kekuatan yang ada untuk mengembangkan persatuan dan kesatuan yang baru tumbuh sehingga mewujudkan satu kesatuan sosial dan satu kesatuan politik yang ada. Pembinaan masyarakat yang baru ini sangatlah penting sebab untuk menghindari konflik karena adanya latar belakang yang berbeda dan yang lebih membahayakan lagi adalah adanya ancaman Yahudi yang tidak suka dengan pembentukan masyarakat baru kaum Muslimin. ${ }^{8}$

\footnotetext{
${ }^{8}$ Muhammad Husain Haekal, Sejarah Hidup Muhammad..., hlm. 34
} 
Dalam pembinaan Madinah Sebagai sebuah negara Muslim tidak terlebas dari sebuah Undang-undang yang dapat diartikan bahwa: Muhammad sebagai Seorang Kepala Negara, Kota Madinah Sebagai wilayah kekuasaannnya, Piagam Madinah Sebagai Undang-undang dasarnya, Orang Islam, Yahudi dan Penyembah berhala sebagai masyarakatnya. Sedangkan fungsi dari undang-undang tersebut adalah: Menyatukan Suku Aus dan Khadzraj, Nabi Muhammad SAW adalah hakim dan kepala Negara, Kebebasan Rakyat terjamin, mengembangkan sikap toleransi antar mat dan menghentikan adat istiadat buruk bangsa Arab. Pada negara barunya Muhammad sebagai sosok teladan ideal yang tidak pernah lemah dalam bersikap sehingga hal ini menjadikan da'wah Islam semakin kuat, meluas dan sanggup menghidupi dan melindungi para pengikutnya tanpa harus mencederai umat lain.

\section{Konsep Islam Tentang Islah, Perdamaian, Persaudaraan}

Perdamaian dalam Islam sering disebut dengan kata islah, yaitu memiliki makna, mendamaikan memperbaiki, menghilangkan sengketa dan kerusakan. Untuk menciptakan sebuah perdamaian, juga dalam membawa keharmonisan, menganjurkan orang untuk berdamai antara satu dan lainnya melakukan perbuatan baik berperilaku sebagai orang mulia. ${ }^{9}$ Di dalam pandangan alquran menjelaskan Islah adalah sebuah kewajiban umat Islam baik secara personal maupun sosial penekanan islah ini lebih terfokus pada hubungan antara sesama umat manusia dalam rangka pemenuhan kewajiban kepada Tuhan.

Kemudian damai mempunyai arti tidak bermusuhan, keadaan tidak bermusuhan, berbaik kembali, tentram, aman, sedang mendamaikan, memperdamaikan yaitu menyelesaikan permusuhan (pertengkaran) supaya kedua belah pihak berbaikan kembali, merundingkan supaya mendapat persetujuan, dan mendamaikan sendiri mempunyai arti sendiri penghentian permusuhan. Ruang lingkup perdamaian sangat luas baik pribadi ataupun sosial. ${ }^{10}$ Dalam mengatasi kemelut dan sengketa dalam rumah tangga dalam Surat An-nisa' ayat 35 Surat tersebut, menegaskan bahwa setiap terjadi persengketaan diperintahkan untuk

\footnotetext{
${ }^{9}$ Tim Penyusun, Ensiklopedi Hukum Islam, (Jakarta: PT. Intermansa, 1997), hlm. 740

10 W.J.S. Poerwa Darminta, Kamus Umum Bahasa Indonesia, (Jakarta: P.N. Balai Pustaka: Cet, Ke-8, 1985), hlm. 225.
} 
mengutus pihak ketiga (hakam) dari pihak suami atau istri untuk mendamaikan mereka. $^{11}$

Para ulama menyatakan bahwa kalau hakam berbeda pendapat maka putusan mereka tidak dapat dijalankan dan kalau hakam sama-sama memutuskan untuk mendamaikan suami dan istri kembali, maka putusanya harus dijalankan tanpa minta kuasa mereka. Di kalangan umat Islam dulu juga dikenal dengan adanya tahkim. ${ }^{12}$.

Di dalam Ensiklopedi Hukum Islam tahkim adalah berlindungnya dua pihak yang bersengketa kepada orang yang mereka sepakati dan setujui serta rela menerima keputusanya untuk menyelesaikan persengketaan mereka berlindungnya dua pihak yang bersengketa kepada orang yang mereka tunjuk (sebagai penengah) untuk memutuskan atau menyelesaikan perselisihan yang terjadi di antara mereka yang sedang bersengketa. ${ }^{13}$

Pada pasal 1851 KUH perdata dikemukakan bahwa yang dimaksud dengan perdamaian adalah "suatu persetujuan dimana kedua belah pihak dengan menyerahkan, menjanjikan atau menahan suatu barang, mengakhiri suatu perkara yang sedang bergantung atau mencegah timbulnya suatu perkara". Suatu perdamaian harus ada timbal balik dalam pengorbanan pada diri pihak-pihak yang berperkara maka tiada perdamaian apabila salah satu pihak dalam suatu perkara mengalah seluruhnya dengan cara mengakui tuntutan pihak lawan seluruhnya, demikian pula tidak ada suatu perdamaian apabila dua pihak setuju untuk menyerahkan penyelesaian perkara kepada arbitrase (pemisah) setuju tunduk pada suatu nasehat yang akan diberikan oleh orang ketiga (binded advies). ${ }^{14}$

Dalam Undang-undang No.3 tahun 2006 juga dijelaskan dengan adanya asas wajib mendamaikan. Ini sebagai pedoman untuk para hakim di Pengadilan Agama untuk mengusahakan jalan damai dalam setiap perkara yang masuk di

${ }^{11}$ Aziz Dahlan, et.el., Ensiklopedi Hukum Islam, (Jakarta: PT Ichtiar Baru van Hoeve, 1996), hlm 1750

12 Teungku Muhammad Hasby Ash Ahiddieqy, Al Bayan, Tafsir Penjelas Al-Qur'anul Karim, (Semarang: PT. Pustaka Rizki Putra, 2002), hlm. 193

${ }^{13}$ Aziz Dahlan, Ensiklopedi Hukum Islam...,hlm. 1750

${ }^{14}$ R. Subekti, R. Citro Sudibyo, Kitab Undang-Undang Hukum Perdata, (Jakarta: PT. Pradnya Paramitra, 2005), hlm. 468 
pengadilan. Dari pengertian perdamaian di atas, dapat kita pahami bahwa yang dimaksud dengan upaya damai yaitu usaha yang dilakukan oleh seseorang atau suatu badan hukum untuk mengadakan pemecahan persoalan dengan cara menghindari persoalan yang lebih fatal. ${ }^{15}$ Di mana dalam hal ini tidak boleh memaksakan kehendak dari pihak-pihak yang bertikai mendamaikan hanya memberi nasehat dan anjuran untuk membatalkan gugatan tersebut dan menyelesaikanya dengan jalan damai. Pelaksanaan upaya perdamaian ini tidaklah mudah, sebab orang yang sedang bersengketa hatinya masih tertutup dan diselimuti rasa tidak suka dan kebencian yang sangat dalam. ${ }^{16}$

Anjuran damai sebenarnya dapat dilakukan kapan saja sebelum perkara belum diputus, tetapi anjuran damai pada permulaan sidang pertama adalah mutlak dan wajib dilakukan dan dicantumkan dalam berita acara persidangan karena ada keharusan yang menyatakan demikian, walaupun mungkin secara logika, kecil sekali kemungkinanya. Dalam usaha mewujudkan perdamaian melibatkan beberapa pihak antara lain ${ }^{17}$ Pihak yang berselisih dan pendamai atau hakam yang diangkat dari pihak hakim atau hakamain. ${ }^{18}$

Dalam perdamaian merupakan salah satu asas dari hukum acara yang berlaku di Peradilan Agama sedangkan hukum acara berlaku menurut ketentuan Pasal 154 UU NO.3 tahun 2006 yang berbunyi "Hukum acara yang berlaku pada pengadilan dilingkungan Peradilan Agama adalah hukum acara perdata yang berlaku pengadilan dalam lingkungan Peradilan Umum kecuali yang telah diatur menurut UU'. Dalam hukum acara perdata Islam, secara umum dasar hukum dari perdamaian itu sendiri, di dalam al-Qura'n sudah diterangkan dalam surat an-Nisa' ayat 35 yang berbunyi:

15 Victor M. Situmorang, Perdamaian dan Perwasitan dalam Hukum Acara Perdata, (Jakarta: PT. Bineka Cipta, 1993), hlm. 3.

${ }^{16}$ Lihat HIR Pasal 130-131

17 Raikhan Rashyd, Hukum Acara Peradilan Agama, (Jakarta: CV. Rajawali, Cet I, 1991), hlm. 95-96

${ }^{18}$ Hakamaian berdasarkan pengertian berdasarkan surah an-Nisa' ayat 35 ditafsirkan oleh para ulama' fiqih sebagai juru damai yang terdiri atas wakil dari pihak suami dam wakil dari pihak istri, untuk mencari jalan keluar dari kemelut yang yang dihadapi oleh pasangan suami istri. Lihat dalam kitab Risalatun Nikah, Jakarta : Gema Insani, Press, Cet I, 1999, hlm .158. 
Artinya: "Dan jika kamu khawatirkan ada persengketaan antara keduanya, maka kirimlah seorang hakam. Dari keluarga laki-laki dan seorang hakam dari keluarga perempuan. Jika kedua orang hakam itu bermaksud mengadakan perbaikan, niscaya Allah memberi taufik kepada suami-istri itu. Sesungguhnya Allah Maha mengetahui lagi Maha pengena".(Q.S. an-Nisa': 35)

Dapat dilihat bahwa berdasarkan Pasal 54 UU No.3 tahun 2006 hukum acara pengadilan agama adalah hukum acara yang berlaku di pengadilan umum (hukum acara pengadilan umum) dan juga hukum khusus yang berlaku di pengadilan dalam lingkungan Pengadilan Agama, yang diatur dengan undangundang. Mengenahi hal perdamaian ini, kebanyakan para hakim di pengadilan, khususnya Pengadilan Agama menggunakan landasan hukum sebagai berikut: a. HIR/RBg/BW/UU.No.2 tahun 1986. b. UU No.7 tahun 1989 Pasal 65 dan 82 UU No yang sekarang di amandemen menjadi 3 tahun 2006. c. UU No.1 tahun 1974 Pasal 39. Jo PP No.9 tahun 1975 Pasal 31. d. IMPRES No.1 tahun 1991(KHI). e. Peraturan Mahkamah Agung. f. Kitab-kitab fiqih Islam dan hukum tidak tertulis lainya

Telah dikemukakan bahwa perdamaian adalah persetujuan dari kedua belah pihak yang berperkara untuk mengakhiri suatu sengketa, persetujuan perdamaian haruslah dibuat secara tertulis. Sehubungan dengan hal ini, maka perdamaian yang dilaksanakan di muka persidangan haruslah timbal balik dalam pengorbanan dari pihak-pihak yang berperkara. Bukan perdamaian apabila salah satu pihak mengalah begitu saja dan mengakui semua tuntutan pihak lawan seluruhnya. Demikian juga tidak ada perdamaian apabila dua pihak menyerahkan penyelesaian perkara kepada arbitrase.

Pada sebuah syarat formal dari suatu putusan perdamaian sebagaimana tersebut dalam Pasal 1851 KUH perdata, pasa 130 HIR, dan Pasal 154 R.Bg dapat dikemukakan sebagai berikut: 1. Adanya persetujuan kedua belah pihak. 2 . Mengakhiri sengketa. 3. Perdamaian atas sengketa yang telah ada. 4. Bentuk perdamian harus tertulis. ${ }^{19}$

19 Abdul Manan, Penerapan Hukum Acara Perdata di Lingkungan Peradilan Agama, (Jakarta: Kencana, Cet-3, 2005), hlm. 154. 
Dalam sebuah upaya damai telah ditempuh dan mencapai kesepakatan maka pihak Pengadilan Agama akan segera membuatkan (actavan vergelijk) akta perdamaian mempunyai kekuatan hukum yang sama dengan putusan hakim dan dapat dieksekusi. Apabila ada pihak yang tidak mau mentaati isi perdamaian, maka pihak yang dirugikan dapat memohon eksekusi kepada Pengadilan Agama. Eksekusi dilaksanakan seperti menjalankan putusan hakim biasa. Akta perdamaian hanya bisa dibuat dalam sengketa mengenahi kebendaan saja yang memungkinkan untuk dieksekusi. Dan juga akta perdamaian tersebut tidak dapat dimintakan banding, kasasi ataupun peninjauan kembali. Demikian pula akat perdamaian tidak dapat diajukan gugatan baru lagi. ${ }^{20}$

\section{a. Pengertian Mediasi}

Defenisi mediasi adalah merupakan penyelesaian sengketa melalui proses perundingan para pihak dengan dibantu oleh mediator. ${ }^{21}$ Mediasi juga merupakan proses negosiasi penyelesaian masalah di mana suatu pihak luar yang netral bekerja bersama para pihak yang bersengketa untuk membantu pihak yang bersengketa guna mencapai satu kesepakatan hasil negosiai yang memuaskan kedua belah pihak yang bersengketa. ${ }^{22}$

Jhon W. Head, menjelaskan bahwa mediasi adalah suatu prosedur penengahan di mana seseorang bertindak sebagai "kendaraan" untuk berkomunikasi antar para pihak sehingga pandangan berbeda atas sengketa tersebut dapat dipahami dan mungkin didamaikan, tetapi tanggung jawab utama tercapainya suatu perdamaian tetap berada di tangan para pihak sendiri. Hal ini juga merupakan suatu proses penyelesaian sengketa berdasarkan perundangundangan yang menggunakan jasa mediator, yang bertugas membantu para pihak yang bersengketa untuk mencari penyelesaian yang dapat diterima oleh para pihak guna mengakhiri. ${ }^{23}$

\footnotetext{
${ }^{20}$ A. Muktiarto, Praktek Perkara Perdata Pada Pengadilan Agama,(Yogyakarta: Pustaka Pelajar, 2005), hlm 95.

${ }^{21}$ Peraturan Mahkamah Agung Republik Indonesia No. 2 Tahun 2003 tentang Prosedur Mediasi di Pengadilan, Pasal 1 Butir 6.

${ }^{22}$ Gary Goodpastes, Panduan Negosiai dan Mediasi, (Jakarta: Elips, 1999), hlm. 241

${ }^{23}$ Gatot Sumartono, Arbitrase Dan Mediasi Di Indonesia, (Jakarta: PT. Gramedia Pustaka Utama. 2006), hlm 120.
} 
Untuk itu merupakan suatu proses penyelesaian sengketa berdasarkan perundang-undangan yang menggunakan jasa mediator, yang bertugas membantu para pihak yang bersengketa untuk mencari penyelesaian yang dapat diterima oleh para pihak guna mengakhiri sengketa. Menurut Joni Emirson mediasi sebagai berikut, mediasi adalah upaya penyelesaian sengketa para pihak dengan kesepakatan bersama melalui mediator yang bersifat netral, dan tidak membuat keputusan atau kesimpulan bagi para pihak tetapi menunjang fasilitator untuk terlaksananya dialog antar pihak dengan suasana keterbukaan, kejujuran, dan tukar pendapat untuk tercapainya mufakat. ${ }^{24}$

Jadi pengertian mediasi dalam arti mencari penyelesaian bersama atas suatu sengketa yang dipimpin oleh seorang penengah. Sebenarnya bukan sesuatu yang baru ada kata kunci yang dapat dipakai untuk menerangkan ketidakbaruan mediasi di Indonesia, yaitu musyawarah. Istilah ini bisa disebut juga dengan mediasi tradisional, dalam hal ini biasanya dipertanyakan siapa yang biasanya bertindak atau dipilih sebagai mediator. Pertanyaan ini dapat mengungkap tidak hanya bagaimana proses mediasi itu dilakukan, tetapi juga nilai falsafi mediasi itu sendiri. $^{25}$

Dalam peraturan Mahkamah Agung No.2 tahun 2003 yang ditetapkan pada tanggal 11 september 2003 yang isinya terdairi dari VI bab dan 18 Pasal yang keseluruhanya mengatur tentang prosedur mediasi di pengadilan. Dan mediasi ini merupakan peraturan yang baru dalam dunia peradilan khususnya Peradilan Agama. Karena mediasi ini sebenarnya sebagai salah satu alternatif dalam penyelesaian perkara di lingkungan peradilan. Mediasi ini merupakan salah satu proses lebih cepat dan murah, serta dapat memberikan akses kepada para pihak yang bersengketa untuk memperoleh keadilan atau penyelesaian yang memuaskan atas sengketa yang dihadapi oleh para pihak. ${ }^{26}$

24 Joni Emirson, Alternatif Penyelesaian Sengketa Diluar Pengadilan, (Jakarta : Gramedia Pustaka Utama, 2001), hlm. 69

25 Achmad Gunaryo, Mediasi Peradilan di Indonesia, makalah seminar dengan tema conflict prefention and peace building, semarang 3 Agustus 2006

${ }^{26}$ Undang-undang No.2 Tahun 2003, Pasal 1 Butir 5. 
Pada proses mediasi tidak terlepas dari peran seorang mediator memegang peranan krusial dalam menjaga kelancaran proses mediasi. Mediator adalah pihak yang bersifat netral dan tidak memihak, yang berfungsi membantu para pihak dalam mencari berbagai kemungkinan penyelesaian sengketa.

Mediator mempunyai tugas yaitu: Pertama mediator harus menjalin hubungan dengan para pihak yang bersengketa agar para pihak tidak menjadi takut untuk mengemukakan pendapatnya. Kedua mediator juga harus memilih strategi untuk membimbing proses mediasi dan mengumpulkan serta menganalisa proses mediasi dan latar belakang sengketa. Ketiga mediator harus mampu untuk merumuskan masalah dan menyusun agenda, karena kadang-kadang yang kelihatan dari luar itu sebenarnya yang besar-besarnya saja. Keempat, mediator juga harus mengungkapkan kepentingan tersembunyi dari para pihak. Terkadang ada para pihak yang beritikad tidak baik, dan hal itu tidak boleh. Keenam, mediator juga harus membangkitkan pilihan penyelesaian sengketa, pintar dan jeli dalam memandang suatu masalah. Ketujuh, mediator dapat menganalisa pilihanpilhan tersebut untuk diberikan kepada para pihak dan akhirnya sampai pada proses tawar menawar akhir dan tercapai proses penyelesaian secara formal berupa kesepakatan antar para pihak.

Sebuah Mediasi merupakan salah satu penyelesaian sengketa di lembaga peradilan yang yang melelui proses perundingan para pihak yang dibantu oleh mediator. Munculnya perturan Mahkamah Agung ini sebagai penyempurnaan dari Surat Edaran No 1 tahun 2002 tentang pemberdayaan pengadilan tingkat pertama yang menerapkan lembaga damai. Ini juga sebagai penjabaran dari Pasal 130 HIR atau $154 \mathrm{RBg}$ yang mendorong para pihak yang berperkara untuk menempuh proses perdamaian.

Munculnya peraturan tentang mediasi ini tidak hanya untuk formalitas, saja tapi sebagai wujud dari kepedulian terhadap orang yang sedang berpekara agar dapat diselesaikan dengan cara damai, cepat dan biaya ringan. Dalam penyelesaian sengketa melalui mediasi, para pihak biasanya mampu mencapai kesepakatan di antara mereka sehingga manfaat mediasi sangat dirasakan. Bahkan dalam mediasi yang gagal, meskipun belum ada penyelesaian yang dicapai, proses 
mediasi yang sebelumnya berlangsung telah mampu mengklarifikasi persoalan dan mempersempit perselisihan. Dengan demikian, para pihak dapat memutuskan penyelesaian seperti apa yang dapat mereka terima dari pada mengejar hal-hal lain yang tidak jelas.

Kegunaan dengan munculnya peraturan ini bagi pengadilan sebagi salah satu alternatif penyelesaian sengketa banyak sekali di antaranya adalah sebagai berikut: 1 . Memperbaiki komunikasi antar pihak dan membantu menurunkan dan melepaskan kemarahan terhadap pihak lawan. 2. Menggali kekuatan dan kelemahan posisi masing-masing pihak. 3. Mediasi akan menfokuskan para pihak pada kepentingan mereka secara nyata dan pada kebutuhan emosi atau psikologi mereka, jadi bukan hanya pada hak-hak hukumnya. 4. Memperoleh ide yang kreatif untuk menyelesaikan sengketa. 5. Menghemat waktu, tenaga dan biaya jika dibandingkan dengan proses litigasi. 6. Dapat memberikan akses kepada para pihak yang bersengketa untuk untuk memperoleh keadilan. 7. Mediasi memberikan hasil yang tahan uji dan akan mampu menciptakan saling pengertian yang lebih baik diantara para pihak yang bersengketa karena mereka sendiri yang memutuskannya. 8. Dapat mengurangi penumpukan perkara di Pengadilan.

Hal ini bertujuan untuk lebih menekankan tentang upaya perdamaian di pengadilan dan juga sebagi penyempurna dari peraturan-peratuan yang dulu tentang adanya pelembagaan perdamaian yang selama ini upaya damai di pengadilan seakan-akan hanya sebagai formalitas saja bukan sebagai anjuran yang ditekankan oleh undang-undang dan juga sebagai landasan hukum pengadilan dalam penyelesaian perkara dan mediasi ini diambil ketika para pihak menghendaki sengketa diselesaikan secara damai.

Dalam sebuah mediasi berakhir hal ini akan membawa konsekuensi bagi para pihak. Terdapat bebrapa kemungkinan berakhirnya mediasi dengan konsekuensi sebagi berikut: 1. Masing-masing pihak memiliki kebebasan setiap saat untuk mengakhiri mediasi hanya dengan menyatakan diri menarik diri. 2. Jika mediasi berjalan dengan sukses, para pihak menandatangani suatu dokumen yang menuraikan beberapa persyaratan penyelesaian sengketa. 3. Jika mediasi tidak berhasil pada tahap pertama, para pihak mungkin setuju untuk menunda 
sementara mediasi. selanjutnya, jika mereka ingin meneruskan atau mengaktifkan kembali mediasi hal tersebut akan memberikan kesempatan terjadinya diskusi baru, yang sebaiknya dilakukan pada titik dimana pembicaran sebelumnya ditunda. ${ }^{27}$

Untuk sebuah perdamaian banyak sekali kegunaan yang didapat dari hasil perdamaian tersebut. Dalam kasus-kasus perdata di pengadilan contohnya jika sengketa yang terjadi dalam masyarakat efeknya pasti terjadi ketegangan terhadap hubungan antara pihak-pihak yang bersengketa. Hal ini berarti hubungan antara yang bersengketa ini telah bergeser dari posisi semula berlandaskan kekeluargaan, persaudaraan, dan persahabatan menjadi hubungan yang berdasarkan rasa permusuhan dan kebencian. Kalau sengketa tersebut tidak segeradi selesaikan maka akan terjadi kehancuran hubungan antara yang bersengketa.

Sebuah penyelesaian melalui pengadilan sebenarnya bukan cara yang paling tepat, memang pengadilan dapat menyelesaiakan perkara dengan adanya putusan dari pengadilan, namun berakhirnya sengketa di pengadilan hanyalah secara lahiriyah. Hal ini merupakan konsekuensi dari putusan pengadilan yang hanya berdasarkan fakta obyektif, tidak menyangkut fakta subyektif, sehingga putusan pengadilan selalu menyatakan ada pihak yang kalah dan ada pihak yang menang. Pihak yang kalah akan merasakan kekecewaan dan tidak begitu saja mengakui kekalahanya. Ketidakmauan pihak yang kalah menerima begitu saja dapat dilihat pada sikapnya yang apriori menerima putusan hakim, dan juga didasari rasa emosi demi menjaga nama baik dan harga dirinya. Sehingga ada upaya hukum yang banding dan kasasi. ${ }^{28}$

Adanya upaya hukum tersebut, maka akan memakan waktu yang cukup lama dan juga biaya yang tidak sedikit. Semua ini bertolak belakang dengan upaya perdamaian. Upaya perdamaian diliput dengan suasana kekeluargaan diantara para pihak yang bersengketa. Dalam suatu perdamaian tidak ditonjolkan faktor-faktor siapa yang salah dan siapa yang benar, namun lebih menonjolkan

27 Gatot Sumartono, Arbitrase Dan Mediasi Di Indonesia, (Jakarta: PT. Gramedia Pustaka Utama. 2006), hlm. 150

${ }^{28}$ Abdul Manan, Penerapan Hukum Acara Perdata di Lingkungan Peradilan Agama, (Jakarta: Kencana, Cet-3, 2005), hlm. 245 
rangkaian duduk perkara yang sebenarnya, sehingga perumusan perdamaian tidak menghasilkan pihak yang kalah maupun pihak yang menang dan yang lebih penting antara para pihak ada niat "mau sama mau". Manfaat sistem perdamaian menyelesaikan sengketa yang dilakukan dengan perdamaian akan menghasilkan kepuasan lahiriyah dan batiniah serta sengketa selesai samasekali, penyelesaianya cepat dan ongkosnya ringan, selain dari pada itu permusuhan antara kedua belah pihak yang berperkara menjadi berkurang. Hal ini jauh lebih baik dari pada apabila perkara sampai diputus dengan suatu putusan biasa, misalnya tergugat dikalahkan dan pelaksanaan putusan harus dilaksanakan secara paksa. ${ }^{29}$

Apabila perkara yang sudah diajukan di pengadilan, dan majlis hakim dapat mendamaikan para pihak, maka hakim harus membuat putusan perdamaian. Sehubungan dengan hal itu ada beberapa manfaat yang dapat diambil dari wujud perdamaian yang dibuat dalam bentuk putusan perdamaian yaitu: pertama mempunyai kekuatan hukum tetap Pasal 1851 KUHP dikemukakan bahwa semua putusan perdamaian yang dibuat dalam sidang Majlis Hakim mempunyai kekuatan hukum tetap seperti putusan pengadilan lainya dalam tingkat penghabisan. Kedua tertutup upaya banding dan kasasi, sebagaimana telah dikemukakan diatas bahwa putusan perdamaian itu adalah sama nilainya dengan putusan pengadilan lainya yang telah mempunyai kekuatan hukum tetap. Hal ini berarti terhadap putusan perdamaian ini tertutup upaya banding dan kasasi. Artinya sejak di tetapkanya putusan tersebut maka sudah melekat bahwa putusan perdamaian itu adalah pasti dan tidak ada penafsiran lagi langsung dapat dilaksanakan kapan saja. Ketiga memiliki kekuatan eksekutorial, Putusan perdamaian yang dibuat dalam persidangan Majelis Hakim mempunyai kekuatan hukum mengikat, mempunyai hukum eksekusi, dan mempunyai nilai pembuktian. ${ }^{30}$

${ }^{29}$ Retnowulan Sutantio, Iskandar Oeripkartawinata, Hukum Acara Perdata dalam Teori dan Praktek, (Bandung: Mandar Maju, 1997), hlm. 36

${ }^{30}$ Abdul Manan, Penerapan Hukum Acara Perdata di Lingkungan Peradilan Agama, (Jakarta: Kencana, Cet-3, 2005), hlm. 124 


\section{Penutup}

Setiap manusia dianugrahi kecerdasan dan keinginan dipercaya oleh Allah untuk menjadi pemimpin dengan mengemban untuk menjaga bumi dari kehancuran. Untuk menjadi seimbang antara kedua kekuatan yang dimiliki manusia tersebut Islam adalah jawabannya. Oleh sebab itu Allah mengutus para nabi Allah dalam menyebarkan ajaran-ajaran yang dapat menjadi kedamainan manusia dalam mengarungi bahtera kehidupan ini. Islam merupakan penyempurna dari ajaran-ajaran sebelumnya. Dan ia adalah agama samawi terakhir yang dibawa oleh rasul terakhir dan untuk umat terakhir yang hidup di zaman akhir. Dengan berpedoman pada alQuran dan sunnah, maka Islam mampu menjawab tantangan zaman semenjak kemunculannya, zaman ini hingga yang akan datang.

Islam hadir untuk menjadi penyelamat dunia sebagai rahmatan lil alamin, dengan demikian setiap ajaran Islam memiliki nilai kebenaran yang tidak diragukan lagi. Ia berusaha menciptakan perdamaian di bumi sehingga umat manusia dan seluruh makhluk Allah dapat hidup sejahtera. Islam dengan pengertian epistimologi memiliki makna penyerahan diri, pasrah, patuh dan tunduk kepada kehendak Allah, ia adalah agama yang membawa kemaslahatan bagi pemeluknya baik di dunia maupun di akhirat. Merupakan suatu kenikmatan besar dapat menjadi Muslim yang kafah.

Manusia sebagai mahluk sosial, yang selalu berhubungan antara satu sisi kehidupan yang lainnya. Maka benturan dan konflik terkadang tidak dapat dihindarkan yang terjadi di tengah kehidupan. Untuk itu Islam hadir dalam kehidupan manusia untuk memberikan jalan mendamaikan permasalahan yang terjadi di kehidupan umat. Sesuai dengan firman Allah "Sesungguhnya orang yang beriman itu bersaudara, maka damaikanlah, apabila diantara saudaramu yang berselisih dan bertikai, bertaqwalah kepada Allah mudah-mudahan kamu memperoleh rahmat"'(QS. al-Hujarat : 10). Dakwah mediasi merupakan salah satu jalan yang sudah di terapkan sepanjang sejarah Islam dan di terapkan hingga sekarang. 


\section{DAFTAR PUSTAKA}

Aziz Dahlan, et.el., Ensiklopedi Hukum Islam, Jakarta: PT Ichtiar Baru van Hoeve, 1996.

Abdul Manan, Penerapan Hukum Acara Perdata di Lingkungan Peradilan Agama, Jakarta: Kencana, Cet-3, 2005.

A.Muktiarto, Praktek Perkara Perdata Pada Pengadilan Agama, Yogyakarta: Pustaka Pelajar, 2005.

Achmad Gunaryo, Mediasi Peradilan di Indonesia, makalah seminar dengan tema conflict prefention and peace building, semarang 3 Agustus 2006

Badri Yatim, Historiografi Islam, Jakarta :Logos Wacana Ilmu, 1997,

Gary Goodpastes, Panduan Negosiai dan Mediasi, Jakarta: Elips, 1999.

Gatot Sumartono, Arbitrase Dan Mediasi Di Indonesia, Jakarta: PT. Gramedia Pustaka Utama. 2006

Joni Emirson, Alternatif Penyelesaian Sengketa Diluar Pengadilan, Jakarta : Gramedia Pustaka Utama, 2001.

Gatot Sumartono, Arbitrase Dan Mediasi Di Indonesia, Jakarta: PT. Gramedia Pustaka Utama. 2006.

Muh. Asnawi, Sejarah Kebudayaan Islam Jilid 3, Aneka Ilmu : Semarang, 2008.

Muhammad Husain Haekal, Sejarah Hidup Muhammad, 1984, Jakarta : Tintamas Indonesia.

Peraturan Mahkamah Agung Republik Indonesia No. 2 Tahun 2003 tentang Prosedur Mediasi di Pengadilan, Pasal 1 Butir 6.

Retnowulan Sutantio, Iskandar Oeripkartawinata, Hukum Acara Perdata dalam Teori dan Praktek, Bandung: Mandar Maju, 1997.

R. Subekti, R. Citro Sudibyo, Kitab Undang-Undang Hukum Perdata, Jakarta: PT. Pradnya Paramitra, 2005.

Raikhan Rashyd, Hukum Acara Peradilan Agama, Jakarta: CV. Rajawali, Cet I, 1991.

Tim Penyusun, Ensiklopedi Hukum Islam, Jakarta: PT. Intermansa, 1997.

Teungku Muhammad Hasby Ash Ahiddieqy, Al Bayan, Tafsir Penjelas AlQur'anul Karim, Semarang: PT. Pustaka Rizki Putra, 2002.

Tim Penulis Al Mizan, Ringkasan Materi Al Mizan, 2001, Mizan Press, Purwokerto.

Undang-undang No.2 Tahun 2003, Pasal 1 Butir 5.

Victor M. Situmorang, Perdamaian dan Perwasitan dalam Hukum Acara Perdata, Jakarta: PT. Bineka Cipta, 1993.

W.J.S. Poerwa Darminta, Kamus Umum Bahasa Indonesia, Jakarta: P.N. Balai Pustaka: Cet, Ke-8, 1985.

Zuhairini, Sejarah Pendidikan Islam, Cet VI, ,Bumi Aksaara : Jakarta. 2006.

Zulkarnain, Muhammad dan Peletakan Hazar Aswad, Disarikan dari seri kajian sirah Nabawiyah di Masjid Salman ITB pada 11 Januari 2011. http://salmanitb.com/2011/01/16/muhammad-dan-peletakan-hajar-aswad/, di akses pada tanggal 11 November 2015 pada pukul 22.30 WIB 